\title{
$\mathrm{ZnO}$ 에서 질소 불순물에 의한 p-type Capacitance
}

\section{P-type Capacitance Observed in Nitrogen-doped ZnO}

\author{
유 현 근 ${ }^{*}$ 김 세 동** 이 동 훈*** 김 정 환 ${ }^{\S}$ 조 중 열 ${ }^{*}$ \\ (Hyungeun Yoo $\cdot$ Sedong Kim $\cdot$ Donghoon Lee $\cdot$ Junghwan Kim $\cdot$ Jungyol Jo)
}

\begin{abstract}
We studied p-type capacitance characteristics of ZnO thin-film transistors (TFT's), grown by metal organic chemical vapor deposition (MOCVD). We compared two ZnO TFT's: one grown at $450^{\circ} \mathrm{C}$ and the other grown at $350^{\circ} \mathrm{C}$. $\mathrm{ZnO}$ grown at $450^{\circ} \mathrm{C}$ showed smooth capacitance profile with electron density of $1.5 \times 10^{20} \mathrm{~cm}^{-3}$. In contrast, ZnO grown at $350^{\circ} \mathrm{C}$ showed a capacitance jump when gate voltage was changed to negative voltages. Current-voltage characteristics measured in the two samples did not show much difference. We explain that the capacitance jump is related to p-type $\mathrm{ZnO}$ layer formed at the $\mathrm{SiO}_{2}$ interface. Current-voltage and capacitance-voltage data support that $\mathrm{p}^{- \text {type }}$ characteristics are observed only when background electron density is very low.
\end{abstract}

Key Words : ZnO, MOCVD, CV characteristics, TFT, Nitrogen, Display

\section{Introduction}

Zinc oxide $(\mathrm{ZnO})$ has attracted considerable attention as promising semiconductor for utilization in display devices. Various growth methods, such as molecular beam epitaxy [1,2], sputtering [3], pulsed laser deposition [4], and metalorganic chemical vapor deposition (MOCVD) [5] have been used. Among these, MOCVD has advantages for industry applications, because it can be applied to large size substrates more easily. MOCVD-grown $\mathrm{ZnO}$ thin-film transistors (TFT) usually show large negative threshold voltage due to native defects, and this problem was solved by using growth interruptions [6].

Another important issue in MOCVD grown $\mathrm{ZnO}$ is realization of $\mathrm{p}$-type TFT. One of the difficulties of p-type doping in $\mathrm{ZnO}$ is due to the self-compensation process. The donor-like native defects, such as zinc interstitial and oxygen vacancy, are dominant defects in $\mathrm{ZnO}$, resulting in $\mathrm{n}$-type behavior. In order to achieve p-type conduction in $\mathrm{ZnO}$, these donor-like defects should be suppressed or eliminated. According to Zhang et al. [7] and Lee et al., [8] the donor-like defects can be suppressed at oxygen-rich (O-rich) condition, and it was possible to obtain intrinsic $\mathrm{p}$-type conduction in $\mathrm{ZnO}$.

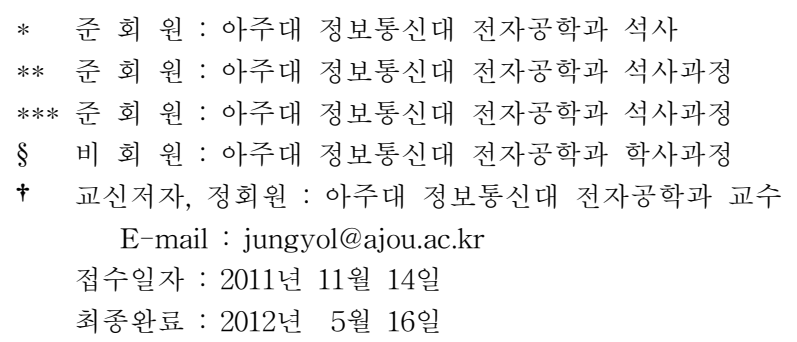

However, under the O-rich condition, the concentration of acceptor-like defects such as zinc vacancy, oxygen interstitial, and oxygen antisite remains low due to their high formation enthalpies. Nevertheless, p-type $\mathrm{ZnO}$ thin fims can be realized without doping by suppressing the donor-like defects [9-12].

We studied $\mathrm{p}$-type characteristics of $\mathrm{ZnO}$ films by measuring capacitance characteristics. Capacitance data can give local information about carrier type and density at a specific depth. Our results show that capacitance increases at negative gate voltages, and we interpret that as an evidence of $\mathrm{p}$-type $\mathrm{ZnO}$.

\section{Experimental Results}

Our MOCVD system has a horizontal reactor operating at atmospheric pressure. $\mathrm{ZnO}$ films were grown at temperatures between 350 and $650^{\circ} \mathrm{C}$. Diethylzinc (DEZ) was used for $\mathrm{Zn}$ source, and $\mathrm{O}_{2}$ was used for $\mathrm{O}$ source. DEZ was fed through a bubbler kept at $10^{\circ} \mathrm{C}$. with a $\mathrm{N}_{2}$ flow of $40 \mathrm{sccm}$. $\mathrm{N}_{2}$ was employed as a carrier gas with a flow of $4000 \mathrm{sccm}$, and $\mathrm{O}_{2}$ flow was $2500 \mathrm{sccm}$. $\mathrm{ZnO}$ films were grown on heavily doped $\mathrm{p}$-type $\mathrm{Si}$ substrates $\left(10^{19} \mathrm{~cm}^{-3}\right)$ with a thermal oxide of $150 \mathrm{~nm}$ thickness. The thickness of $\mathrm{ZnO}$ film was between 30 and $50 \mathrm{~nm}$. TFT structure was fabricated by evaporating Al through a shadow mask (channel length $=15 \mu \mathrm{m}$, width $=500 \mu$ $\mathrm{m})$. Excess $\mathrm{ZnO}$ film outside of active device area was etched away by diluted acetic acid, while the TFT was protected by photoresist. Capacitance was measured by an Agilent E4980A LCR meter, with frequencies between 1 $\mathrm{kHz}$ and $1 \mathrm{MHz}$. Currents were measured by Keithley 2400 sourcemeters. 
Fig. 1 shows p-type capacitance measured in $\mathrm{ZnO}$ films. Nitrogen was introduced into $\mathrm{ZnO}$ during $\mathrm{N}_{2}$ annealing at $800^{\circ} \mathrm{C}$. Capacitance increased at negative gate voltages, which indicates positive charge increase in $\mathrm{ZnO}$. P-type capacitance was observed up to $1 \mathrm{MHz}$ frequency. It is known that nitrogen introduces acceptor level at 200 $\mathrm{meV}$ above valence band edge. The $800^{\circ} \mathrm{C}$ annealing converted $\mathrm{n}$-type $\mathrm{ZnO}$ to an insulator, because the newly added acceptor levels decreased background electron density significantly.

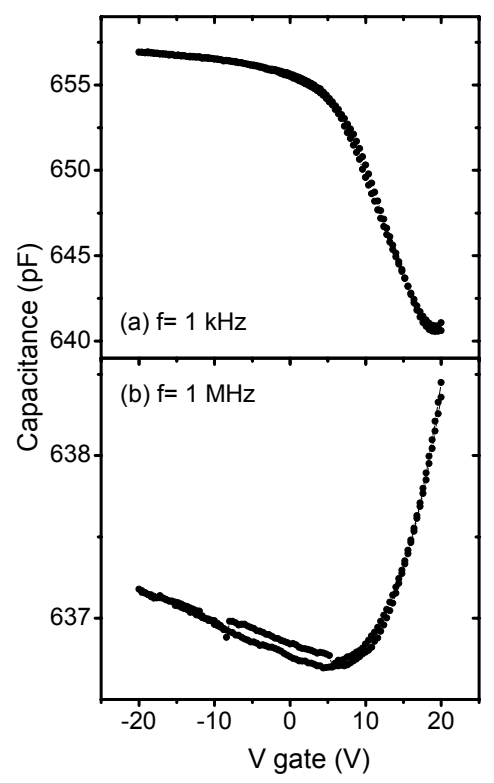

Fig. 1 P-type capacitance measured in $\mathrm{ZnO}$, at (a) $1 \mathrm{kHz}$ and (b) $1 \mathrm{MHz}$ frequencies. Capacitance increases at negative gate voltages.

p-type capacitance was also observed in $\mathrm{ZnO}$ samples grown at $350^{\circ} \mathrm{C}$. Figs. 2 and 3 are current and capacitance characteristics measured in two TFT's, one grown at $450^{\circ} \mathrm{C}$. (Fig. 2), and the other at $350^{\circ} \mathrm{C}$ (Fig. 3). The figures show that capacitance data are very different, although current data are almost identical. Fig. 2 shows typical n-type capacitance characteristics, but Fig. 3 shows large capacitance jumps at zero gate voltage. It is known that at the initial stage of $\mathrm{ZnO}$ growth there are intermediate layers, which have different electrical characteristics than the normal $\mathrm{ZnO}$ layer. It appears that these intermediate layers have $\mathrm{p}$-type characteristics, which can explain the large capacitance jumps.

In Fig. 4, p-type TFT currents were observed when carrier density was very low, and the drain currents showed space-charge limited behavior. Space-charge limited current shows non-linear voltage dependence, because the applied voltage increases carrier density. This effect can be more pronounced when carrier density is very low. It appears that underlying $\mathrm{p}$-type currents

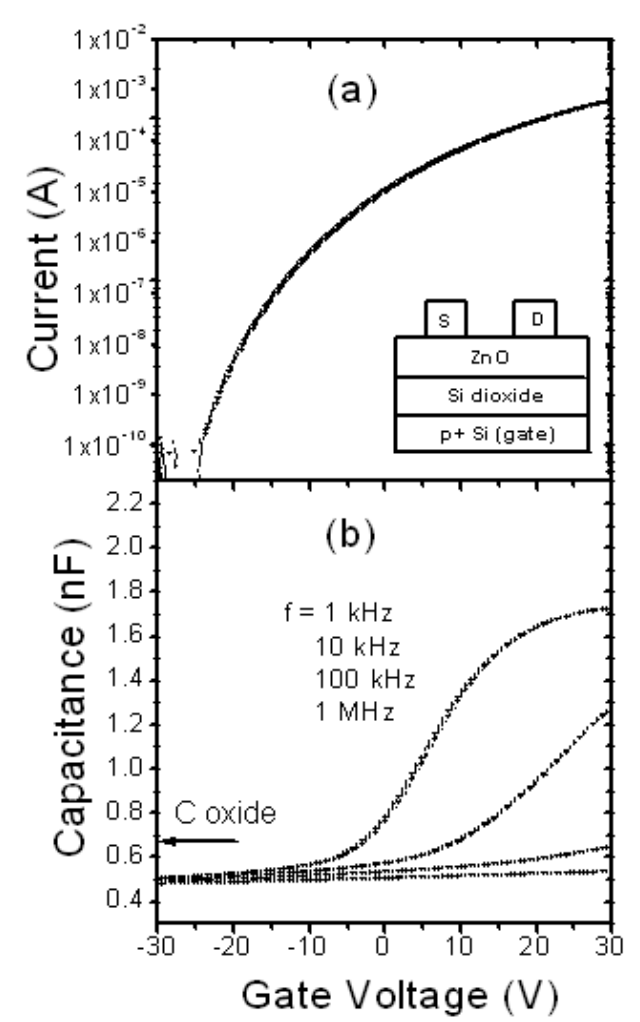

Fig. 2 Current-voltage (a) and capacitance-voltage (b) characteristics of ZnO TFT grown at $450 \mathrm{oC}$.

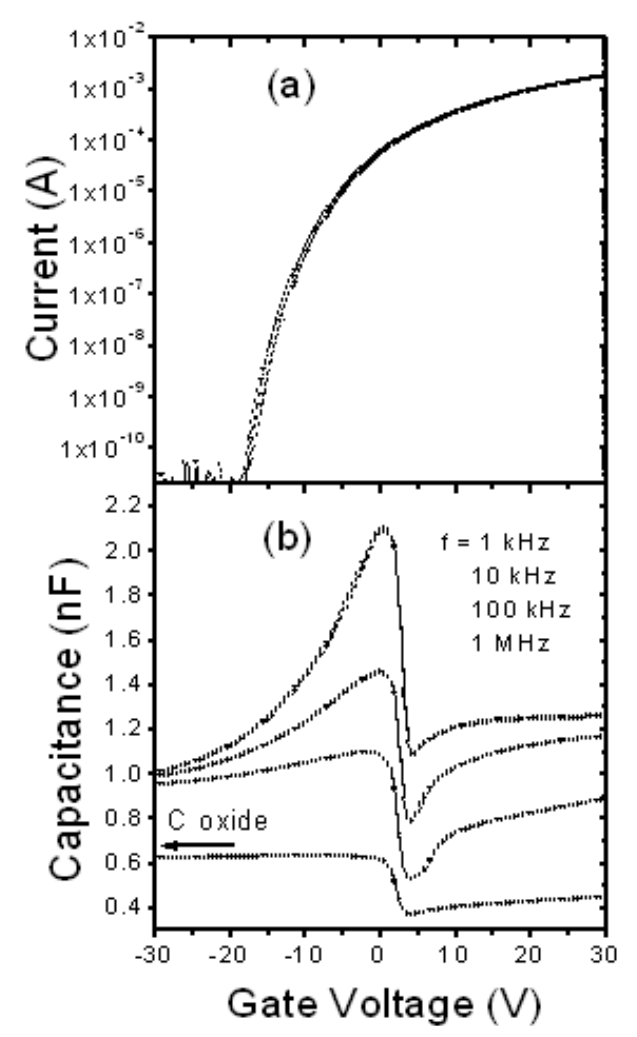

Fig. 3 Current-voltage (a) and capacitance-voltage characteristics of ZnO TFT grown at $3500 \mathrm{C}$. 


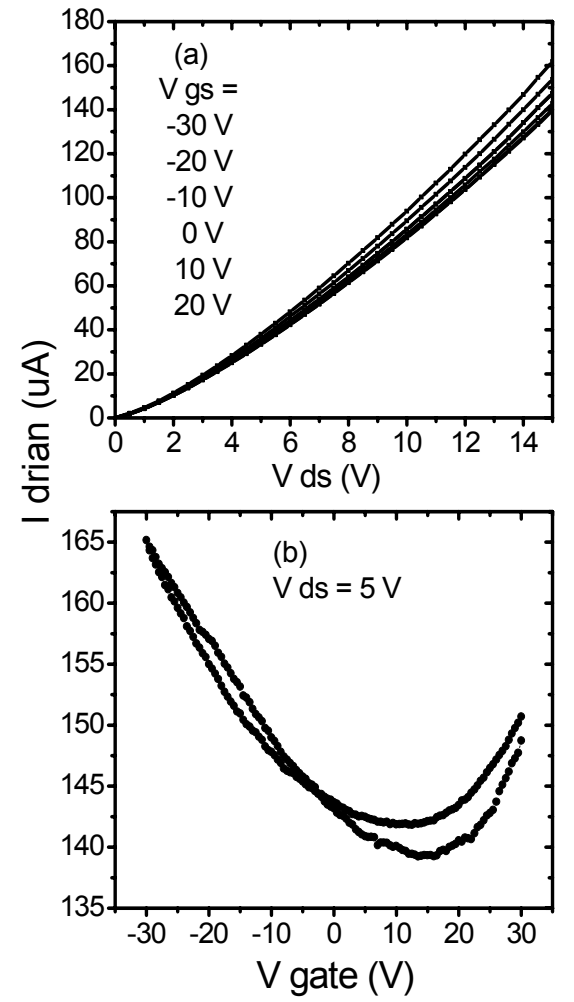

Fig. 4 TFT currents measured by sweeping (a) drain-source voltage and (b) gate-source voltage. Although currents increase at negative gate voltages, they show space-charge limited current.

become more pronounced when n-type defects are removed.

\section{Conclusions}

We demonstrated realization of $\mathrm{p}$-type characteristics in $\mathrm{ZnO}$ grown by MOCVD. Nitrogen was used for $\mathrm{p}$-type dopants. Capacitance increased at negative gate voltages, and we interpret that as a result of $\mathrm{p}$-type $\mathrm{ZnO}$. P-type current-voltage characteristics were measured in $\mathrm{ZnO}$ TFT structure, but the current was low because carrier density was decreased by compensation.

\section{Acknowledgements}

This research was supported by Basic Science Research Program through the National Research Foundation of Korea (NRF) funded by the Ministry of Education, Science and Technology (NRF-2010-0016669).

\section{References}

[1] K. Miyamoto, M. Sano, H. Kato, and T. Yao, "Effects of $\mathrm{ZnO} / \mathrm{MgO}$ Double Buffer Layers on
Structural Quality and Electron Mobility of $\mathrm{ZnO}$ Epitaxial Films Grown on c-Plane Sapphire," Jpn J. Appl. Phys. vol. 41, pp. L1203-L1205, 2002.

[2] A. Tsukazaki, M. Kubota, A. Ohtomo, T. Onuma, K. Ohtani, H. Ohno, S. Chichibu, and M. Kawasaki, "Blue Light-Emitting Diode Based on ZnO," Jpn J. Appl. Phys. vol. 44, L643-L645, 2005.

[3] H. Q. Chiang, J. F. Wager, R. L. Hoffman, J. Jeong, and D. A. Keszler, "High Mobility Transparent Thin-Film Transistors with Amorphous Zinc Tin Oxide Channel Layer," Appl. Phys. Lett. vol. 86, p. 13503, 2005.

[4] K. Nomura, H. Ohta, A.Takagi, T. Kamiya, M. Hirano, and H. Hosono, "Room-temperature Fabrication of Transparent Flexible Thin-Film Transistors Using Amorphous Oxide Semiconductors," Nature vol. 432, pp. 488-492, 2004.

[5] J. Jo, O. Seo, E. Jeong, H. Seo, E. Jeong, H. Seo, B. Lee, and Y. I. Choi, "Effect of Hydrogen in Zinc Oxide Thin-Film Transistor Grown by Metal Organic Chemical Vapor Deposition," Jpn J. Appl. Phys. vol. 46, 2493-2495, 2007.

[6] J. Jo, O. Seo, H. Choi, and B. Lee, "Enhancement-Mode ZnO Thin-Film Transistor Grown by Metalorganic Chemical Vapor Deposition," Appl. Phys. Express vol. 1, p. 041202, 2008.

[7] S. B. Zhang, S. H. Wei, and A. Zunger, "Intrinsic n-type versus p-type Doping Asymmetry and the Defect Physics of ZnO," Phys. Rev. B vol. 63, p. 075205, 2001.

[8] E. C. Lee, Y. S. Kim, Y. G. Jin, and K. J. Chang, "Compensation Mechanism for N Acceptors in ZnO," Phys. Rev. B vol. 64, p. 085120, 2001.

[9] Y. Ma, G. T. Du, S. R. Yang, Z. T. Li, B. J. Zhao, X. T. Yang, T. P. Yang, Y. T. Zhang, and D. L. Liu, "Control of Conductivity Type in Undoped $\mathrm{ZnO}$ Thin Films Grown by Metalorganic Vapor Phase Epitaxy," J. Appl. Phys. vol. 95, pp. 6268-6271, 2004.

[10] T. V. Butkhuzi, A. V. Bureyev, A. N. Georgobiani, N. P. Kekelidze, and T. G. Khulordava, "Optical and Electrical Properties of Radical Beam Gettering Epitaxy Grown $\mathrm{n}^{-}$and p-type $\mathrm{ZnO}$ Single Crystals," J. Cryst. Growth vol. 117, pp. 366 - 369, 1992.

[11] A. N. Georgobiani, M. B. Kotlyarevskii, V. V. Kidalov, L. S. Lepnev, and I. V. Rogozin, "Luminescence of Native-Defect p-Type ZnO," Inorg. Mater. vol. 37, pp. 1095-1098, 2001.

[12] G. Xiong, J. Wilkinson, B. Mischuck, S. Tuzemen, K.B.Ucer, and R.T. Williams, "Control of $\mathrm{p}^{-}$and n-type Conductivity in Sputter Deposition of Undoped ZnO," Appl. Phys. Lett. vol. 80, p. 1195, 2002. 


\section{저 자 소 개}

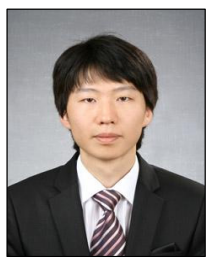

유 현 근 (俞 鉉 根)

아주대학교 물리학 학사

아주대학교 전자공학 석사

삼성전자 DS

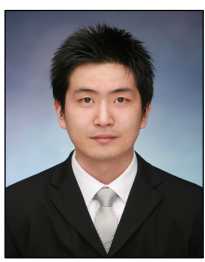

김 세 동 (金世 東)

아주대학교 전자공학 학사 아주대학교 전자공학 석사

삼성 모바일 디스플레이

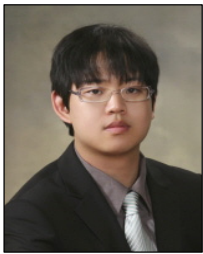

이 동 훈 (李 東 勳)

아주대학교 물리학 학사

아주대학교 전자공학 석사과정

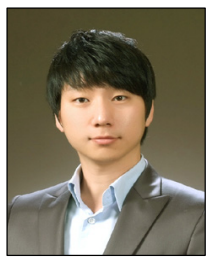

김 정 환 (金 正 煥)

아주대학교 전자공학 학사

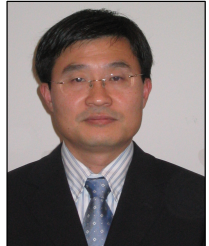

조 중 열 (曺 重 烈)

서울대학교 전자공학 학사

미국 Princeton 대학교 박사

아주대학교 교수 